\title{
PERLINDUNGAN HUKUM BAGI PEMEGANG MEREK TERKENAL DI INDONESIA
}

\author{
Muhamad Shafwan Afif, Heru Sugiyono \\ Fakultas Hukum Universitas Pembangunan Nasional Veteran Jakarta, Jakarta \\ muhamadshafwanafif@upnvj.ac.id
}

\begin{abstract}
Abstrak
Penelitian mengenai perlindungan hukum bagi merek terkenal di Indonesia bertujuan untuk mengetahui perlindungan hukum bagi merek terkenal berdasarkan hukum positif di Indonesia dengan unsur persamaan pada pokoknya. Merek terkenal memiliki sifat ekslusif, namun masih terdapat banyak pelanggaran yang menimpanya seperti peniruan, pemboncengan dan hal-hal yang membuat rugi pemilik merek terkenal. Hal ini perlu dilakukan analisis agar terciptanya persaingan usaha yang sehat dalam dunia industri. Dalam penelitian ini menggunakan metode yuridis normatif. Penelitian ini memiliki kebaharuan yaitu pembahasan lebih mengkhususkan tentang regulasi merek terkenal di Indonesia atas dasar persamaan pada pokoknya dan tanggung jawab lembaga negara yaitu DJKI terhadap merek yang dibatalkan oleh pengadilan karena memiliki persamaan pada pokoknya dengan merek terkenal. Hasil penelitian yaitu untuk perlindungan hukum terhadap merek terkenal saat ini diatur sebatas kriteria merek terkenal, larangan melakukan tindakan yang mengandung unsur persamaan pada pokoknya dengan merek terkenal dan upaya represif berupa hak melapor kepada pengadilan yang dimiliki oleh merek terkenal, hal ini tertuang didalam UU No. 20 tahun 2016 tentang Merek dan Indikasi Geografis, Permenkumham No. 67 tahun 2016 yang mengatur mengenai pendaftaran merek, serta Yurispudensi Mahkamah Agung No. 022/HKI/2012. Bentuk tanggung jawab dari DJKI adalah dengan menjalankan putusan pengadilan, melakukan penyuluhan hukum dan dapat dipidana sesuai ketentuan KUHP.
\end{abstract}

Kata Kunci ; Hukum; Merek Terkenal; Tanggungjawab

\section{LEGITIMATE PROTECTION FOR INDONESIAN RENOWED BRAND HOLDERS}

\begin{abstract}
The composition on legitimate protection for notable imprints in Indonesia means to discover the lawful insurance for notable imprints dependent on certain law in Indonesia with a component of uniformity fundamentally. Notable brands have an elite nature, yet there are as yet numerous infringement that happen to them like impersonation, pillion and things that put on the map brand proprietors lose. This should be investigated to make solid business contest in the modern world. This review utilizes a standardizing juridical technique. In this review, the oddity is that the conversation centers more around the guideline of notable brands in Indonesia based on essential likenesses and the obligations of the state office, specifically DJKI, for brand names that are dropped by the court since they have similitudes on a basic level with notable brands. The aftereffects of the review are that legitimate security for notable brands is presently controlled to the degree of notable brand standards, restriction of making moves that contain components of similitude on a basic level with notable brands and oppressive endeavors as the option to answer to the court claimed by notable brands, this is expressed in the UU no. 20 of 2016 concerning Brands and Geological Signs, Permenkumham No. 67 of 2016 concerning Brand name Enrollment and High Court Law No. 022/HKI/2012. The type of liability of the DJKI is to do court choices, give lawful guiding and can be rebuffed by the arrangements of the Criminal Code.
\end{abstract}

Keywords ; Legal, Famous Brand, Responsibility 


\section{A. PENDAHULUAN}

Di Indonesia fenomena pelanggaran kepada pemilik sah dari merek terkenal yang sudah diakui undang-undang dan pengadilan banyak terjadi, hal ini disebabkan karena gampangnya menemukan berbagai jenis-jenis produk yang dijual bebas dipasaran, mulai dari pasar traditional, toko-toko kecil bahkan sampai yang menjual dipinggir jalan menggunakan kendaran pribadi, lebih mirisnya produk yang diperjual-belikan merupakan suatu produk dengan brand atau merek terkenal. Barang-barang tersebut biasanya diperjual-belikan dengan harga yang miring dari harga aslinya, bahkan harganya ini terkadang sampai berbeda sangat jauh dari harga normalnya yang dimiliki dari merek terkenal yang sudah diakui oleh negara, namun banyak konsumen yang tidak mengetahui cara membedakan barang atau produk yang telah diakui oleh negara yang asli atau tiruan, bahkan tidak sedikit adanya iktikad tidak baik dari konsumen berupa sengaja membeli barang palsu, bagi mereka tentu pastinya sangat tertarik untuk membeli barang dengan harga murah walaupun yang mereka beli barang palsu (KW).

Berdasarkan permasalahan tersebut sudah terdapat unsur pelanggaran bagi merek terkenal dengan sangat jelas, hal ini ditandai dengan pemroduksian/memperdagangkan produk tiruan (KW) kepada konsumen, pelanggaran yang marak tejadi termasuk kedalam unsur persamaan secara fundamental jika kita mengacu kepada undang-undang nomor 20 tahun 2016 tentang Merek dan Indikasi Geografis (MIG). kepastian perlindungan hukum bagi merek terkenal merupakan suatu keharusan, dengan alasan bahwa dengan adanya kepastian hukum bagi pemegang merek-merek tersebut yang sudah diketahui oleh masyarakat luas (terkenal), guna memberikan hak ekslusif dan meberikan rasa aman kepada pemilik hak merek tersebut sesuai dengan prinsip principle of legal certainty di Indonesia.

Merek terkenal mempunyai sifat ekslusif/hak ekslusif yang didapatnya berdasarkan beberapa persyaratan yang berada dalam undang-undang Merek (UU MIG) dan Permenkumham tentang pendaftaran merek, hal ini harus dilindungi melalui undang-undang positif tertulis. Undang-Undang MIG telah menerangkan bahwa "setiap merek baru yang ingin mendaftarkannya kepada negara tidak boleh memiliki persamaan secara fundamental terhadap merek terkenal yang telah diakui oleh negara", maka apabila terdapat indikasi persamaan pada permohonan pendaftaran merek, merek baru tersebut harus langung ditolak menimbang unsur kemiripan secara fundamental terutama dengan merek terkenal.

Disamping itu hal yang perlu diperhatikan juga mengenai tanggung jawab dari Direktorat Jenderal Kekayaan Intelektual (DJKI) selaku lembaga negara yang berkecimpung dalam dunia kekayaan intelektual di Indonesia seperti merek, sebagai lembaga negara yang independent dan garda terdepan dalam menyeleksi 
merek baru yang ingin didaftarkan kepada negara maka sudah sepatutnya jika terdapat merek dengan indikasi pelanggaran berupa persamaan secara fundamental langsung ditolak oleh lembaga tersebut, namun sampai saat ini masih banyak merek yang melakukan penjiplakan merek terkenal, hal ini menjadi bukan sebuah rahasia umum lagi bahwa lembaga negara tersebut bekerja kurang profesional dan tidak menjadikan UU MIG sebagai salah satu pedoman dalam menerbitkan sebuah merek baru.

Dalam kenyataanya masih terdapat beberapa kasus dimana dalam satu merek dagang dengan lainnya memiliki unsur persamaan fundamental (basically the same), contohnya kasus merek "EIGER" yang dimana dalam kasus itu yaitu Ronny Lukito selaku penggugat dan pemilik sebuah merek terkenal Eiger melakukan gugatan perdata kepada Budiman Tjoh selaku pemilik merek Eiger lainnya, namun jika melihat merek tersebut maka merek pemilik dari tergugat merupakan sebuah merek yang memiliki kemiripan fundamental dengan merek Eiger yang dimiliki dan dipegang hak mereknya oleh penggugat, kemudian didalam perkara tersebut dijelaskan bahwa kedua merek tersebut yang memiliki kemiripan dalam hal nama dan juga pelafalannya dan sama-sama terdaftar didalam kelas 25 , namun untuk pendaftarannya terlebih dahulu dilakukan oleh merek terdaftar tergugat yang melakukannya.

Jika kita melihat dari kasus ini maka secara sepintas kita melihat adanya ketidakjelasan dari lembaga negara yaitu kementrian hukum dan hak asasi manusia Republik Indonesia terutama dalam hal ini DJKI selaku pemilik kebijakan tentang pendaftaran, dengan alasan bahwa dalam undang-undang nama merek dan tanda-tanda fundamental telah ditegaskan dalam pasalnya bahwa "setiap merek yang didaftarkan tidak dapat terkabulkan atau ditolak jika memiliki kemiripan secara fundamental dengan merek terkenal”, kemudian juga didalam pasal lainnya diterangkan yaitu "merek terkenal yang dimaksud dalam undangundang ini yaitu merek yang sejenis ataupun yang berbeda jenis." Dalam 2 pasal sudah secara jelas diatur, namun pada kenyatannya masih belum dapat teralisasikan dengan baik terutama mengenai unsur kemiripan secara fundamental. Setelah melihat penjelasan singkat diatas maka penelitian ini meneliti bentuk tanggung jawab yang dilakukan oleh DJKI atas kelalaianya.

Penelitian mengenai perlindungan terhadap merek terkenal telah banyak dilaksanakan oleh penelitian teradahulu, untuk contohnya yaitu penelitian Iqbal (2021) yang berjudul 'Legal Protection of Famous Trademarks' yang berfokuskan kepada analisis peneliti terhadap keberhasilan regulasi merek terkenal di Indonesia. Kelebihan dari penelitian ini terletak dari pengamatan yang dilakukan tentang merek terkenal dan regulasinya, karena regulasi khusus mengenai merek terkenal belum termuat di Indonesia, saat ini yang termaktub didalam undang- undang MIG hanya pernyataan "merek tidak dapat melakukan 
pendaftaran jika memiliki kemiripan secara fundamental dengan merek terkenal" sehingga banyak kelemahan yang termuat diundang-undang ini seperti maksud dari persamaan secara fundamental seperti apa. ${ }^{1}$ Kekurangan dari penelitian ini yaitu tidak dijelaskan mengenai akibat hukum dari pelanggar merek terkenal dan upaya preventif dari DJKI, berdasarkan uraian tersebut maka dalam penelitian ini memiliki perbedaan yaitu membahas mengenai tanggungjawab DJKI yang dikaitkan kedalam ranah hukum perdata dan pidana, bentuk tanggungjawab yang dilakukan DJKI dengan menghapuskan/membatalkan merek yang memiliki persamaan secara fundamental dengan merek terkenal atas dasar putusan pengadilan dan memberikan denda kepada pelaku pendomplengan merek serta DJKI juga dapat terkena perbuatan pidana berupa penyelewengan dalam jabatan.

Penelitian lain yang dilakukan oleh Desmayanti (2018) dengan judul "Tinjauan Umum Perlindungan Merek Tekenal Sebagai Daya Pembeda Menurut Prespektif Hukum di Indonesia," dalam penelitian ini menganalisis mengenai hubungan antara undang-undang nomor 20 tahun 2016 tentang MIG dan juga Permenkumham Nomor 67 tahun 2016 tentang Pendaftaran Merek, dengan penyelesaian sengketa merek terkenal yang dilakukan oleh pengadilan negeri di Indonesia. Di penelitian ini memiliki kelebihan, karena menjelaskan bahwasannya undang-undang merek terkenal saat ini masih belum dapat berfungsi secara baik dan belum memiliiki unsur kepastian hukum, Hal ini terlihat dari setiap pilihan yang memiliki komponen yang sama, lebih tepatnya kedekatan pada tingkat dasar namun memiliki hasil putusan yang beragam. ${ }^{2}$ Kekurangan dari penelitian ini yaitu tidak dijelaskan secara eksplisit mengenai persamaan secara fundamental, berdasarkan uraian tersebut maka dalam penelitian ini memiliki perbedaan yaitu membahas mengenai unusr persamaan secara fundamental berdasarkan teori-teori yang relevan.

Sedangkan penelitian yang dilakukan oleh Mangowal (2017) yang berjudul "Perlindungan Hukum merek Terkenal Dalam Perspektif Undang-undang Nomor 20 tahun 2016 tentang Merek," melakukan analisis mengenai regulasi hukum untuk merek terkenal dan juga melakukan penelitian tentang pelanggaran merek dapat diatasi melalui penanganan pidana, perdata, adminitrasi negara, pabean, badan standar industri, banda standar periklanan. Kelebihan dari penelitian ini adalah menjabarkan sudut pandang penanganan baru selain melalui jalur keperdataan (hukum perdata), tetapi dapat melalui yang lainnya. ${ }^{3}$ Kekurangan dari penelitian ini yaitu tidak dijelaskan mengenai akibat hukum yang dapat diterima oleh DJKI, berdasarkan uraian tersebut maka dalam penelitian ini

\footnotetext{
${ }^{1}$ Mohammad Iqbal and Erdyanto Dwi Nugroho, "Legal Protection Of Famous Trademarks," USM Law Review 4, no. 1 (2021): 105-16, https://doi.org/https://doi.org/10.26623/julr.v4i1.3460.

${ }^{2}$ Rakhmita Desmayanti, "Tinjauan Umum Perlindungan Merek Terkenal Sebagai Daya Pembeda Menurut Prespektif Hukum Di Indonesia,” Jurnal Cahaya Keadilan 6, no. 1 (April 30, 2018): 1-21, https://doi.org/10.33884/jck.v6i1.874.

3 Jacklin Mangowal, "Perlindungan Hukum Merek Terkenal Dalam Perspektif Undang-Undang Nomor 20 Tahun 2016 Tentang Merek," Lex Et Societatis 5, no. 9 (2017): 22-29.
} 
memiliki perbedaan yaitu membahas mengenai akibat hukum yang dapat diterima DJKI yang dikaitkan kedalam ranah hukum perdata dan pidana, bentuk akibat hukum yang dapat diterima DJKI dapat berupa denda administrasi dan hukuman pidana sesuai KUHP.

Penelitian terdahulu berfokuskan kepada sudut pandang efektifitas dan kejelasan undang-undang perlindungan merek mengenai merek terkenal, serta dikaitkan dengan putusan pengadilan tertentu, namun disisi lain terdapat kekurangannya seperti peran dari instansi negara belum dijelaskan. Sedangkan penelitian ini memiliki novelty, mengkhususkan tentang regulasi merek terkenal di Indonesia atas dasar persamaan secara fundamental dan tanggung jawab lembaga negara. Tujuan penelitian adalah untuk menganalisa perlindungan hukum bagi merek terkenal berdasarkan hukum positif di Indonesia atas dasar persamaan secara fundamental dan tanggungjawab dari DJKI selaku lembaga negara terhadap merek yang dibatalkan oleh pengadilan negeri karena memiliki unsur persamaan secara fundamental dengan merek terkenal serta akibat hukum yang dapat diterima oleh DJKI selaku lembaga negara.

\section{B. PERMASALAHAN}

1. Bagaimana perlindungan hukum bagi pemegang merek terkenal atas adanya permohonan pendaftaran merek yang mempunyai "persamaan pada pokoknya" di Indonesia?

2. Bagaimana tanggungjawab Direktorat Jenderal Kekayaan Intelektual (DJKI) yang telah melakukan pendaftaran merek, namun dibatalkan oleh pengadilan niaga karena dinyatakan memiliki persamaan pada pokoknya dengan merek terkenal?

\section{METODE PENELITIAN}

Penelitian hukum ini menggunakan metode yuridis normatif atau penelitian hukum doktrinal, yaitu 'pendekatan dengan menjelajahi bahan pustaka atau informasi data sekunder, kemudian dianalisis menurut sudut pandang peraturan perundang-undangan dan norma-norma yang selaras dengan masalah yang ada' ${ }^{4}$ Penelitian ini menekankan kepada deskriptif analistis, yaitu melihat teori-teori yang relevan dan dikaitkan dengan hukum positif yang berlaku, serta penerapan praktiknya yang selinier dengan permasalahan dalam penelitian ini. Untuk bahan yang menjadi sumber dan data yang digunakan dalam penelitian hukum ini ialah data sekunder yang didapat dari memadukan bahan-bahan hukum yang ada, yaitu bahan hukum primer, bahan hukum sekunder, dan bahan hukum tersier. Teknik pengumpulan data dalam penelitian menggunakan library research (penelitian kepuskatakaan) yang memiliki makna bahwa penelitian dilakukan dengan meneliti artikel ilmiah yang sudah ada sebagai bahan pustaka (data sekunder). Teknik analisis data menggunakan kualitatif normatif, yaitu data yang sudah didapat kemudian diteliti secara sistimatis, serta melakukan analisis dengan

${ }^{4}$ Mukti Fajar \& Yulianto Ahmad, Dualisme Penelitian Hukum Normatif \& Empiris (Yogyakarta: Pustaka Pelajar, 2017). 
metode kualitatif normatif dengan tujuan memperoleh kejelasan dari permasalahan yang diteliti. Tujuan dipilihnya analisa ini adalah agar mendapatkan berbagai sudut pandang mengenai penerapan peraturan perundang-undangan di Indonesia yang mengatur implementasi undang-undang nomor 20 tahun 2016 tentang merek (UU MIG) sehingga akhirnya mendapatkan gambaran regulasi hukum yang berkaitan dengan permasalahan diterapkannya perlindungan hukum bagi merek terkenal di Indonesia atas dasar persamaan secara fundamental dan tanggung jawab dari DJKI terhadap merek yang di batallkan pengadilan.

\section{HASIL DAN PEMBAHASAN}

\section{Perlindungan Hukum Bagi Pemegang Merek Terkenal atas adanya Permohonan Pendaftaran Merek Yang Mempunyai "Persamaan Pada Pokoknya" Di Indonesia}

Merek sebagai suatu karya hasil dari ide dan pemikiran yang digabungkan satu sama lain dengan tujuan sebagai branding dalam sebuah product bisnis yang bernilai ekonomi, baik didalam negeri, khususnya publik maupun diluar wilayah Indonesia (secara universal) tentu memiliki banyak bahaya sebagai peniruan merek, terutama yang kini dikenal luas dengan panggilan merek terkenal. ${ }^{5}$ Jaminan sah yang diperlukan oleh merek-merek terkenal untuk menjaga reputasi, citra baik dan hak keekslusifannya terteta secara definitif dalam undang-undang MIG mengenai merek terkenal yang didalam tatanannya menjelaskan bahwa 'calon pemohon pendaftar, baik yang mengatasnamakan individu maupun yang beratasnamakan sebuah badan hukum tidak dapat melakukan registrasi jika merek tersebut mempunyai persamaan secara fundamental dengan merek terdaftar yang terkenal dan diterima oleh pengadilan baik merek sejenis ataupun berbeda jenis dari merek yang ingin melakukan registrasi kepadan lembaga berwenang, dalam konteks ini adalah DJKI, agar terciptanya rasa aman bagi pemilik merek terkenal yang sudah diakui oleh negara'. Jenis kepastian hukum yang diberikan oleh perundang-undangan tentang MIG, kepada merek terkenal ialah merek terkenal dapat melakukan gugatan penghapusan atau royemen merek, ditujukkan pada negara melalui pengadilan niaga di Indonesia, gugatan ini dapat beradasarkan adanya kemiripan secara fundamental dengan merek terdaftar yang terkenal. ${ }^{6}$

Hukum memiliki komitmen untuk menjamin kecenderungan seseorang dengan memberikan kapasitas baginya untuk bertindak dalam memuaskan kecenderungannya sesuai jalur yang berlaku, terukur sesuai kapasitasnya. Pendapat dikemukakan oleh Philipus M.Hadjon yaitu bahwa standar kepastian hukum yang sah bagi orang-orang terhadap kegiatan pemerintah bersandar pada pengakuan dan jaminan kebebasan bersama mengingat fakta bahwa seperti yang ditunjukkan oleh sejarah dibarat, pengenalan ide-ide pengakuan dan jaminan pada

${ }^{5}$ Rahmadia Maudy Putri Karina and Rinitami Njatrijani, "Perlindungan Hukum Bagi Pemegang Hak Merek Dagang IKEA Atas Penghapusan Merek Dagang," Jurnal Pembangunan Hukum Indonesia 1, no. 2 (May 29, 2019): 194-212, https://doi.org/10.14710/jphi.v1i2.194-212.

${ }^{6}$ Zaenal Arifin and Muhammad Iqbal, "Perlindungan Hukum Terhadap Merek Yang Terdaftar," Jurnal Ius Constituendum 5, no. 1 (2020): 56-60, https://doi.org/https://doi.org/10.26623/jic.v5i1.21172. 
kebebasan bersama ditujukan pada batas-batas dan menetapkan komitmen pada masyarakat dan otoritas publik. Hipotesis hukum dan ketertiban pada dasarnya menyiratkan bahwa hukum adalah tak tertandingi dan komitmen masing-masing negara bagian atau eksekutif pemerintah tunduk pada hukum (bergantung pada hukum), tidak ada paksaan yang dikecualikan dari aturan yang diikuti orang lain (dikecualikan dari aturan yang diikuti semua orang), semuanya berada dibawah hukum (dibawah hukum dan ketertiban), dengan dalam situasi ini, tidak boleh ada kekuatan subjektif (kekuatan diskresioner) atau sekali lagi penganiayaan kekerasan.

Dalam penggunaan hukum yang sah untuk merek-merek terkenal di Indonesia unsur yang penting yaitu unsur persamaan secara fundamental, pendapat mengenai unsur ini dikemukakan oleh Beverly W. Pattishall didalam tulisannya menyebutkan bahwa faktor yang dapat menjadi tolak ukur untuk mengetahui adanya Persamaan secara fundamental adalah sebagai berikut :

a. Paralelisme tampilan (Similitude of Appreance);

b. Kata asing (Unfamiliar Terms);

c. Paralelisme kedekatan arti (Closeness of Meaning);

d. Paralelisme kata dan tanda gambar (Word and Picture Imprints);

e. Paralelisme kedekatanvsuara (Closeness of Sound) ${ }^{7}$

Dalam menerapkan perlindungan hukum untuk merek populer, lembaga yang berada digarda terdepan adalah DJKI, pengadilan negeri, mahkamah agung serta pemilik merek terkenal yang sudah terdaftar itu sendiri. Setiap lembagalembaga tersebut tentu memiliki peranan masing-masing. ${ }^{8}$ DJKI berperan untuk memfilter merek yang memiliki kemiripan secara fundamental dengan merek terkenal saat registrasi merek baru melalui bank data lembaga, pengadilan negeri terutama pengadilan niaga berperan untuk memutuskan secara adil dan saksama jika terdapat perkara dengan unsur persamaan secara fundamental, mahkamah agung berperan seperti pengadilan negeri namun dalam tingkatan yang lebih tinggi dan putusan yang lebih kuat kemudian, terakhir adalah pemilik merek terkenal itu sendiri berperan untuk mengawasi merek-merek yang baru terdaftar.

Kemudian jika terdapat indikator persamaan secara fundamental maka memiliki kesempatan untuk mengajukan gugatan pembatalan atau royemen merek, setiap lembaga yang turut andil harus secara konsisten mematuhi dan menyetujui undang-undang dan pedoman yang berlaku dan relevan. ${ }^{9}$

\footnotetext{
7 Legalakses.com, “'Persamaan Pada Pokoknya' Dalam Hak Merek,” Legalakses.com, n.d., https://www.legalakses.com/persamaan-pada-pokoknya/.

${ }^{8}$ Wahyudy Falarungi, Hambali Thalib, and Syamsuddin Pasamai, "Penegakan Hukum Terhadap Penjualan Pakaian Merek Palsu Di Pasar Senteral Kota Makassar," Journal of Lex Philosophy (JLP) 1, no. 2 (December 19, 2020): 151-62, https://doi.org/10.52103/jlp.v1i2.214.

${ }^{9}$ Sendy Anugrah, "Unsur Persamaan Pada Pokoknya Dalam Pendaftaran Merek Menurut UndangUndang Nomor 20 Tahun 2016 Tentang Merek Dan Indikasi Geografis Dan Penerapannya Dalam Praktik Dihubungkan Dengan Pelanggaran Terhadap Merek Terkenal," Aktualita (Jurnal Hukum) 2, no. 1 (July 19, 2019): 18-37, https://doi.org/10.29313/aktualita.v2i1.4663.
} 
Menurut Jimly Asshiddiqie maksud dari kata penegakan hukum ialah proses yang ditempuh agar berfungsi dan tegaknya norma-norma hukum secara riil sebagai acuan perilaku hubungan hukum, antara marwah bermasyarakat dan negara. ${ }^{10}$ Dari sudut pandang konsepsional dapat diartikan bahwa penegakan hukum menurut Soerjono Soekanto adalah gerakan menyesuaikan hubungan kualitas yang dijelaskan dalam pedoman yang sesuai dan ditunjukkan dalam mentalitas aktivitas sebagai perkembangan dari pertemuan tertentu, evaluasi yang ditentukan untuk membuat, mengikuti, dan menjaga aktivitas publik yang tenang. ${ }^{11}$ Ruang lingkup dalam penegakan hukum berdasarkan pendapat Jimly Asshiddiqie, dapat dijumpai sebagai unsur manusia atau orang, kemudian kedua, institusi, badan atau organisasi dengan kualitas lembaganya sendiri-sendiri. ${ }^{12}$ Berdasarkan uraian tersebut disimpulkan bahwa keamanan yang sah (hukum) terhadap merek-merek terkenal di Indonesia, yang memiliki peran vital adalah aparatur penegak hukum. Apabila dalam tugasnya aparatur penegak hukum tidak dapat bekerja secara profesional maka tidak akan melahirkan masyarakat yang taat pada hukum. ${ }^{13}$

Peraturan perundang-undangan dan pedoman preservasi yang sah secara hukum sangat jelas dan tegas tertuang dalam Pasal 21 UU MIG. ${ }^{14}$ Merek dapat menjadi merek populer jika memenuhi kualifikasi yang tertera dalam peraturan perundang-undangan di Indonesia, misalnya dalam Pasal 83 ayat 2 UU MIG dapat disimpulkan bahwa merek terkenal disahkan berdasarkan keputuan pengadilan yang berwenang dan dalam klarifikasi Pasal 21 ayat 1 huruf b UU MIG yaitu merek tersebut sudah banyak diketahui masyarakat umum, memiliki citra baik yang dihasilkan berupa kualitas dan branding, terdapat keterangan telah terdaftar di negara asing.

Kemudian, dalam Pasal 18 ayat 3 Permenkumham Merek disebutkan syarat menjadi merek terkenal seperti adanya pengetahuan dan pengakuan dari masyarakat bahwa merek tersebut terkenal, volume barang keluar dan laba pemilik merek, lundang pasar yang dikuasi oleh merek tersebut, jangkauan wilayah dan waktu merek tersebut dipergunakan, tingkat intensitas dari branding merek tersebut dan investasi, merek tersebut telah mengajukan permohonan pendaftaran merek di negara lain, putusan pengadilan yang mengkonfirmasikan

10 Jimly Ashidqie, Menuju Negara Hukum Yang Demokratis (Jakarta: Sekretariat Jenderal dan Kepaniteraan Mahkamah Konstitusi, 2008).

${ }^{11}$ Sarjono Soekanto, Faktor-Faktor Yang Mempengaruhi Penegakan Hukum (Jakarta: Rajawali Pers, 2012).

${ }^{12}$ Laurensius Arliman S, Menuju Negara Hukum Yang Demokratis (Yogyakarta: Deepublish, 2015).

13 Sherly Ayuna Putri, Tasya Safiranita Ramli, and Hazar Kusmayanti, "Penyelesaian Sengketa Merek Terkenal Sephora Atas Dasar Persamaan Pada Pokoknya Berdasarkan HIR Dan Undang-Undang Nomor 15 Tahun 2001 Tentang Merek," Jurnal Hukum Positum 4, no. 2 (December 21, 2019): 57-67, https://doi.org/10.35706/positum.v4i2.3182.

${ }^{14}$ Pemerintah Pusat, "Undang-Undang (UU) Tentang Merek Dan Indikasi Geografis," Pub. L. No. 20 (2016), https://peraturan.bpk.go.id/Home/Details/37595/uu-no-20-tahun-2016. 
bahwa merek tersebut adalah merek populer. ${ }^{15}$ Selain 2 peraturan tersebut terdapat statuta pengadilan tinggi Republik Indonesia nomor 022K/HaKI/2002. Menurut majelis hakim kriteria merek populer ialah masyarakat umum sangat mengetahui merek didalam jenis usaha tersebut, bagusnya reputasi merek yang didapatkan melalui branding yang secara continue dan pemiliknya berinvestasi dibeberapa negara, telah terbukti terdaftar di negara lain secara sah. ${ }^{16}$ Baik dalam undangundang atau peraturan lainnya yang paling utama adalah iktikad baik dari masayarakat luas dalam menerapkan dan melaksanakan peraturan-peraturan tersebut.

Budaya hukum dapat diartikan sebagai kebulatan faktor yang dapat menentukan sistem hukum mendapatkan tempatnya yang nyata dalam ruang lingkup masyarakat umum. Pelaksanaan perlindungan hukum merek terkenal dalam hal ini bergantung kepada individu setiap lembaga. ${ }^{17}$ Pribadi tersebutlah yang berperan penting dalam mengawasi para penegak hukum terkait perlindungan merek terkenal ini. Disamping itu budaya hukum masyarakat menjadi faktor nyata agar hak ekslusif dari merek terkenal yang sudah terlindungi oleh hukum atas merek, tetap dipertahankan dan memberikan keyakinan bahwa semuanya baik-baik saja bagi pemilik merek yang sah. Budaya hukum pun berperan penting untuk dapat menentukan apakah hukum ini dapat berjalan dengan baik atau sebaliknya. ${ }^{18}$

Teori tentang hukum dikemukakan oleh Gustav Radburch, dia mengatakan bahwa dalam hukum memiliki tiga nilai yang menjadi dasarnya yaitu;

a. Keadilan;

b. Kepastian hukum;

c. Kemanfaatan hukum.

Dalam hipotesisnya, Gustav menjelaskan bahwa 'standar kebutuhan yang berasal dari tiga kualitas esensial adalah tujuan dari sebuah undang-undang'. Hal ini karena pada kenyataannya keadilan yang sah seringkali kontradiktif dengan keyakinan dan kepastian hukum serta sebaliknya. Ketika diantara ketiga nilai dasar tersebut terjadi benturan maka harus ada yang dikorbankan guna terciptanya hukum yang ideal. Menurut Gustav ketiga nilai dasar ini bersifat relatif, dapat berubah-ubah untuk menjadi prioritas dalam peraturan yang berlaku. Hal ini terjadi karena suatu saat hukum tersebut mengutamakan keadilan, namun disaat

15 Kementrian hukum dan HAM, "Peraturan Menteri Hukum Dan HAM Tentang Pendaftaran Merek,” Pub. L. No. 67 (2016), https://peraturan.bpk.go.id/Home/Details/133289/permenkumham-no-67tahun-2016.

${ }^{16}$ Mahkamah Agung, "Yurispudensi Mahamah Agung," Pub. L. No. 22K/HaKI/ (2002).

17 Anajeng Esri Edhi Mahanani, "Rekonstruksi Budaya Hukum Berdimensi Pancasila," Jurnal $\begin{array}{llllll}\text { Yustika Media Hukum Dan Keadilan 22, no. } 2 & \text { (2019): } & 1-10 \text {, }\end{array}$ https://doi.org/https://doi.org/10.24123/yustika.v22i01.

${ }^{18}$ Mukti Fajar, Yati Nurhayati, and Ifrani Ifrani, "Iktikad Tidak Baik Dalam Pendaftaran Dan Model Penegakan Hukum Merek Di Indonesia,” Jurnal Hukum Ius Quia Iustum 25, no. 2 (May 2018): 210-36, https://doi.org/10.20885/iustum.vol25.iss2.art1. 
lain hukum tersebut menonjolkan kepastian hukum, lalu diwaktu yang lain mengunakan kemanfaaatan hukum dalam penerapannya. ${ }^{19}$

Implementasi proteksi terhadap merek populer berdasarkan UU tentang MIG jika ditinjau dari teori dasar hukum yang dikemukakan Gustav Radburch maka lebih condong kepada nilai keadilan serta kepastian hukum, perlindungan bagi merek terkenal sejauh ini diatur dalam Pasal 21 undang-undang nomor 20 tahun 2016 tentang MIG jo Pasal 19 permenkumhan nomor 67 tahun 2016 tentang pendaftaran merek. ${ }^{20}$

Dalam keadilan memiliki perspektif filosofis yakni kaidah hukum, nilai kesamarataan, moral dan terakhir etika. Hukum tercipta sebagai penyelenggara nilai keadilan, kemudian nilai keadilan turut serta menjadi bagian dasar hukum untuk membuat hukum menjadi nyata. Kesamarataan memiliki sifat normatif dan juga konstitutif untuk hukum. Keadilan menjadi dasar dari moral hukum dan sekaligus barometer sistem hukum yang berlaku saat ini (positif), terlebih lagi, dengan asumsi tidak ada kesetaraan, standar, tidak memiliki hak untuk menjadi undang-undang. ${ }^{21}$ Berdasarkan teori keadilan dengan jaminan hukum bagi pemegang merek terkemuka di Indonesia, pelaksanaan jaminan yang sah untuk merek-merek terkenal harus menciptakan rasa ekuitas untuk merek yang berbeda.

Penelitian dari Thoyyibah (2018) menyimpulkan bahwa perlindungan kepada merek terkemuka di Indonesia sudah diatur dalam undang-undang nomor 20 tahun 2016 tentang MIG dan statuta pengadilan tinggi Republik Indonesia Nomor 274 PK/Pdt/2003, disamping itu dalam penelitiannya disimpulkan bahwa merek dikategorikan sebagai merek terkenal dengan syarat masyarakat luas mengetahuinya dan citra kepada merek tersebut yang dapat berupa banyaknya merek tersebut terdaftar dibanyak negara serta branding untuk mengedarkan produknya secara luas. ${ }^{22}$ Penelitian Thoyyibah tersebut dilengkapi oleh Budiman (2019) didalam penelitiannya tentang 'perlindungan hukum terhadap merek terkenal di Indonesia menguraikan bahwa terdapat perjanjian international diterapkan di Indonesia yaitu Trade-Related Aspects of Intellectual Property Right Agreement (TRIPs) yang telah diimplementasikan dalam undang-undang MIG. kemudian dalam penelitiannya juga dijelaskan bahwa suatu merek tidak bisa menyensuskan merek tersebut apabila terdapat kesamaan pada pokoknya dengan merek terkenal sebagaimana diatur didalam Pasal 21 UU MIG. semua unsur-unsur yang dapat dikategorikan sebagai persamaan secara fundamental baik dari sisi penglihatan, pelafalan, huruf dan semacamnya tidak boleh

${ }^{19}$ Muhammad Erwin, Filsafat Hukum (Jakarta: Raja Grafindo, 2012).

20 Tasya Safiranita, Sherly Ayuna Putri, and Hazar Kusmayanti, "Penyelesaian Sengketa Merek Terkenal 'SEPHORA' Atas Dasar Persamaan Pada Pokoknya Berdasarkan Herzien Inlandsch Reglement (HIR) Dan Undang-Undang Merek," Dialogia Iuridica: Jurnal Hukum Bisnis Dan Investasi 9, no. 1 (November 30, 2017): 112-21, https://doi.org/10.28932/di.v9i1.734.

${ }^{21}$ Fenny Cahyani et al., "Kedudukan Hak Imunitas Advokat Di Indonesia," USM Law Review 4, no. 1 (2021): 146-60, https://doi.org/https://doi.org/10.26623/julr.v4i1.3328.

${ }^{22}$ Thoyyibah Bafadhal, "Perlindungan Hukum Terhadap Merek Terkenal Di Indonesia," Undang: Jurnal Hukum 1, no. 1 (June 1, 2018): 21-41, https://doi.org/10.22437/ujh.1.1.21-41. 
terdaftarkan kepada DJKI karena memiliki kemiripan pada dasarnya dengan merek terdaftar yang terkenal. ${ }^{23}$

Dalam penjelasan selanjutnya Pasal 21 UU tentang MIG, sangat terlihat bahwa persamaan secara fundamental adalah 'persamaan yang ditimbulkan dari komponen satu merek dengan merek lainnya, memunculkan perasaan bahwa kemiripan dari segi struktur, situasi, dan sebagainya. teknik, menyusun sistem atau campuran komponen, atau perumpamaan. suara deklamasi yang terkandung dalam merek.

Utrecht menawarkan pandangannya terhadap kepastian hukum, sebagaimana ditunjukkan olehnya, kepastian yang sah mengandung 2 implikasi, yang pertama adalah adanya pedoman umum memuat perbuatan apa yang diperbolehkan dan tidak diperbolehkan oleh setiap individu, kemudian kedua, berupa keamanan hukum yang didapatkan individu untuk menghindari kebijakan tidak mendasar (kesewenangan) pemerintah, sebab dengan peraturan bersifat general maka data diketahui oleh individu, bagaimana perilaku yang bisa dituduh atau ditangani orang oleh negara dan diperbuat oleh individu. ${ }^{24}$

Berdasarkan teori kepastian hukum yang dikemukakan oleh Utrecht maka "perlindungan hukum bagi merek terkenal perlu adanya peraturan secara general dan khusus untuk mengaturnya agar tidak terjadi pelanggaran yang merugikan pemilik hak ekslusif dari merek populer yang telah terdaftar dari unsur persamaan secara fundamental". Di Indonesia perlindungan hukum ini sudah terdapat didalam kebijakan regulasi undang-undang tentang MIG, kemudian terdapat dalam Permenkumham tentang Pendafataran Merek dan statuta pengadilan tinggi Republik Indonesia Nomor 022 K/HaKI/2002.

Perlindungan hukum yang ideal untuk merek terkenal di Indonesia dapat dilakukan dengan memenuhi 2 prinsip penting yaitu tegaknya keadilan dan terwujudnya perdamaian, hal ini dapat diimplementasikan dalam wujud adanya regulasi khusus mengenai merek terkenal yang didalamnya dapat berisi mengenai kriteria merek terkenal secara konkrit, syarat menjadi merek terkenal, adanya sebuah badan pemerintah yang bertugas untuk melakukan survey kepada masyarakat luas mengenai suatu merek guna mempermudah merek baru yang mendaftar agar tidak adanya unsur persamaan secara fundamental dan adanya hukuman selain penghapusan dan pembatalan merek, hukuman dapat berwujud seperti denda atau hukum pidana sesuai ketentuan KUHP. Berdasarkan sudut pandang penelitian ini maka peneliti berpendapat bahwasannya didalam masa digital dan elektronik undang-undang mengenai merek masih relevan untuk digunakan, akan tetapi dalam konteks merek terkenal sudah tidak cukup relevan, sebab masih banyak kekosongan yang terdapat didalamnya seperti hukuman dari pelaku yang sengaja melakukan pendomplengan dan peniruan merek terkenal,

${ }^{23}$ Citra Rosa Budiman, "Perlindungan Hukum Terhadap Merek Terkenal (Well-Known) Di Indonesia," Reformasi Hukum 23, no. 1 (November 27, 2019): 1-18, https://doi.org/10.46257/jrh.v23i1.54.

${ }^{24}$ Syahrani Riduan, Rangkuman Intisari Ilmu Hukum (Bandung: Citra Aditya Bakti, 1999). 
selain itu terkait pihak yang melaporkan didalam undang-undang MIG saat ini hanya subjek hukum yang bersangkutan namun dalam kecanggihan teknologi maka menurut penelitian ini siapa saja dapat melaporkannya kepada kepolisian atau pengadilan sebagai seorang saksi yang disertai bukti substansial sesuai dengan pengaturan undang-undang.

Perlindungan hukum bagi merek terkenal di Indonesia lebih menekankan kepada kepastian hukum untuk penegakannya, yaitu maksudnya adalah dengan adanya hukum tertulis maka terjaminnya merek terkenal dari perbuatan atau perilaku yang bertujuan untuk meniru, mendompleng baik barang sejenis atau berbeda jenis dan senantiasa menjunjung tinggi asas persamaan secara fundamental dengan asas iktikad baik.

\section{Tanggungjawab Direktorat Jenderal Kekayaan Intelektual (DJKI) Yang Telah Melakukan Pendaftaran Merek, Namun Dibatalkan Oleh Pengadilan Niaga Karena Dinyatakan Memiliki Persamaan Pada Pokokya Dengan Merek Terkenal}

Pejabat pemerintahan memiliki wewenang yang ekslusif dan berbeda dari pegawai negeri biasa, namun kewenagan ini senantiasa diiringi oleh tanggungjawab, hal ini berdasarkan prinsip geen bevoegdheid zonder verantwoordenlijkheid yang mengandung pengertian tidak ada kekuasaan tanpa tanggungjawab, maka dalam pelaksanaannya kewajiban dapat dipisahkan menjadi 2 struktur, yaitu kewajiban posisi pertama dan kewajiban moral kedua, hal ini dapat diperhatikan dalam hal bahwa seseorang menyelesaikan sesuatu, demi kepentingan jabatan (ambtshalve), bentuk tanggungjawabnya dalam jabatan seperti ganti rugi dan denda, maka akan ditangguhkan kepada APBN dan APBD, jika perbuatan orang tersebut beratasnamakan pribadi maka bentuk pertanggungjawabannya tidak dibebankan kepada APBN dan APBD akan tetapi bentuknya ganti rugi berupa uang pribadi sebab atas kesalahan pribadi. ${ }^{25} \mathrm{Di}$ Indonesia tanggungjawab pribadi erat kaitannya dengan perbuatan penyimpangan dalam administrasi, regulasi mengenai penyimpangan dalam administrasi saat ini termaktub dalam Pasal 1 angka 3 undang-undang nomor 37 tahun 2008 tentang Ombudsman Republik Indonesia. ${ }^{26}$ berdasarkan dari suatu sudut pandang hukum publik, pertanggungjawaban berhubungan dengan penerapan kewenangan yang bertolak belakang dengan norma hukum, didalamnya termasuk melawan perundang-undangan yang berlaku, kecurangan wewenang yang jelas tidak masuk akal ataupun unsur lain yang mengakibatkan hak-hak dari warga terlanggar. ${ }^{27}$

\footnotetext{
${ }^{25}$ Lutfil Ansori, "Diskresi Dan Pertanggungjawaban Pemerintah Dalam Penyelenggaraan

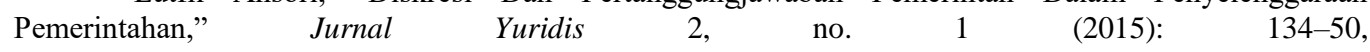
https://doi.org/https://doi.org/10.35586/jyur.v2i1.165.

${ }^{26}$ Pemerintah pusat, "Undang-undang (UU) Tentang Ombudsman Republik Indonesia," Pub. L. No. 37 (2008), https://peraturan.bpk.go.id/Home/Details/39708.

${ }^{27}$ Hertanti Pindayani, "Tanggung Jawab Direktorat Jenderal Hak Kekayaan Intelektual Terhadap Pemegang Hak Atas Merek Dalam Hal Ada Putusan Pembatalan Merek," Authentica 1, no. 1 (December 8, 2018): 42-50, https://doi.org/10.20884/1.atc.2018.1.1.8.
} 
DJKI memiliki tanggung jawab terhadap pendaftaran merek baru, dimulai saat proses verifikasi adminitrastif, dalam proses ini apabila dalam kurun waktu 30 hari tidak ada penafian dari pemilik merek lain terutama yang terdaftar maka proses tersebut berlanjut kepada verifikasi substantif, dilakukan oleh tim khusus dari bagian pemeriksa merek sesuai regulasi yang berlaku, tugas pokok dari bagian pemeriksa merek ini yaitu memvalidasi merek berupa perencanaan, pemeriksaan dan penulusuran dokumen-dokumen dari merek tersebut.

Untuk menganalisis bentuk tanggungjawab dari DJKI maka dalam penelitian ini, menautkan terhadap perkara merek "EIGER" dengan putusan No.41/Pdt.Sus-Merek/2019/PN.Niaga.Jkt,sengketa ini berawal dari perusahaan nasional berdomisili di Bandung yang bergerak dibidang industri rumahan berupa tas sejak tahun 1970-an, penggugat dipercaya untuk menjalankan dan menyebarluaskan produk dari luar negeri melalui perusahannya, penggugat juga membuat lapangan kerja untuk masyarakat Indonesia bernama PT. Eksonindo Multi Product Industri, dan PT. Eigerindo Multi Produk Industri yang bernaung didalam grup usaha bernama B\&B Inc, selain itu penggugat pun diakui sebagai tokoh bisnisman nasional yang ditandai dengan berbagai penghargaan yang diperoleh penggugat dari institusi dalam negeri maupun luar negeri. Penggugat telah mengeluarkan merek "EIGER" dalam perjalanan usahanya yang mengembangkan bisnisnya sejak 1980-an.

Penggugat melakukan pendaftaran merek dagang kepada turut tergugat yaitu DJKI di kelas 25, dengan nomor rencana D00.2014.019111 yang berarti mengamankan jenis produk (pakaian, bra wanita, jas, jas, kemeja, singlet, kaus kaki, sarung tangan, dasi, ikat pinggang, topi, ikat kepala, sepatu, sepatu, selendang, korset, rompi, kerudung, lengan, penutup (songkok), sepatu, sandal, jas, tutup kepala, namun setelah pihak yang dirugikan menyebutkan fakta objektif pada bank informasi termohon, terdapat jejak yang sebanding yang mempunyai persamaan esensial dengan jejak pihak yang dirugikan dengan nomor IDM000495808 di kelas 25 untuk jenis barang dagangan : kaus kaki, gesper (gaun) dan nomor IDM000087029 di kelas 25 untuk produk; kaus kaki, ikat pinggang milik tergugat dengan nama merek "EIGER", hal ini sangat mengusik penggugat sebab tujuan penggugat melakukan pendaftaran merek kepada DJKI untuk mendapatkan perlindungan hukum dan hak ekslusif dari merek 'EIGER' guna keberlangsungan bisnisnya yang beratasnamakan Ronny Lukito.

Untuk mendukung pembuktian dari penggugat maka penggugat melakukan tracking dan penyelidikan mengenai merek tergugat dan menemukan fakta bahwa tidak adanya produk-produk milik tergugat yang menggunakan merek 'EIGER' dalam kelas barang 25, namun tergugat menjalankan bisnisnya dibidang kosmetik yang bernaung dibawah PT. Rantaeus Cipta Pesona, produk yang dihasilkan berupa parfum, deodorant, pomade (minyak rambut) dengan merek 
'AMBASSADOR Eau de Parfum', 'Eiger', 'EVO', 'GARAVANE', 'Venon' dan 'EVELYN', selain itu penggugat juga menerima surat somasi dari tergugat, berisi agar penggugat tidak menggunakan nama 'EIGER' jika tidak maka akan berlanjut ke ranah hukum, tergugat juga meminta restitusi kepada penggugat jika ingin menggunakan merek 'EIGER' untuk kelas barang 25 yang dimiliki oleh penggugat. berdasarkan hal diatas maka dapat disimpulkan bahwa tujuan tergugat adalah ingin mendompleng merek dagang penggugat yang sudah terkenal dengan ketidakjujuran melanggar unsur persamaan secara fundamental dalam undangundang MIG. Menurut penelitian ini alasan penggugat menganggap merek tergugat memiliki persamaan secara fundamental dengan mereknya karena terletak diunsur nama 'EIGER' dan berada di kelas 25 dan jenis barangnya serupa. $^{28}$

Sehubungan dengan hal tersebut, pihak penggugat melaporkannya kepada Pengadilan Niaga Jakarta Pusat melalui gugatan pembatalan merek, sesuai dengan Pasal 76 undang-undang MIG,dalam pasal 20 dan 21 diterangkan bahwa pihak yang memiliki permasalahan dengan pihak lainnya dapat mengajukan gugatan pembatalan merek, selain regulasi tersebut yang menjadi landasan hukum dari penggugat adalah Pasal 21 ayat 1 huruf b yang memiliki makna, pendaftaran harus ditolak jika memiliki kemiripan dengan jelas 'persamaan secara fundamental' dengan merek terkenal baik sejenis ataupun tidak, dalam peraturan internasional juga dijabarkan, berdasarkan pasal 62bis ayat 1 Konvensi Paris menjelaskan bahwasannya, negara yang turut terlibat konvensi harus menolak, membatalkan, dan melarang merek yang merupakan tiruan dari merek-merek terkenal karena dapat mengakibatkan kebingungan dalam masyarakat.

Menurut penelitian ini apa yang dilakukan Pengadilan Niaga Jakarta Pusat sudah benar dengan menerima gugatan yang diajukan oleh penggugat sebagaimana termaktub didalam undang-undang serta regulasi internasional dan dapat teralisasikan dengan cukup baik. Saat ini Indonesia sudah memiliki sistem pendaftaran merek baru dan sudah berjalan dan sesuai regulasi yang ada, akan tetapi menurut penelitian ini masih terdapat kekosongan hukum, hal ini dapat dicirikan dengan belum adanya data mengenai merek terkenal secara jelas, saat ini untuk mengetahui merek tersebut terkenal atau tidak, dapat dilakukan jika pengusaha yang ingin melakukan pendaftaran merek baru melakukan pencarian secara mandiri terkait merek terkenal guna mengetahuinya.

Dalam sengketa merek dagang tersebut, menurut penelitian ini sudah sewajarnya jika merek dagang miliki tergugat ditolak oleh turut tergugat, karena mengingat hal-hal sebagai berikut :

${ }^{28}$ Sukmo Hanggarjito \& Simona Bustani, “Tanggung Jawab Ditjen KI Terhadap Pembatalan Merek Dagang COFFEEBERRY (Studi Putusan Mahkamah Agung Nomor 769K/PDT.SUS.HKI/2019)” 3, no. 1 (2020): 822-40, https://doi.org/https://doi.org/10.24912/adigama.v3i1.8928. 
a. Tergugat memiliki unsur iktikad tidak baik berupa hanya mendaftarkan saja akan tetapi tidak melakukan produksi untuk merek 'EIGER' dan mengancam dalam sebuah surat somasi yang ditujukan kepada penggugat;

b. Merek 'EIGER' milik penggugat telah beroperasi sejak tahun 1970-an, sehingga dapat dikatakan jauh dari merek tergugat yang didaftarkan kepada turut tergugat;

c. Memiliki kemiripan pada tingkat mendasar dengan merek 'EIGER' yang diklaim oleh pihak yang tersinggung, merupakan merek populer dari permainan huruf dan kelas tenaga kerja dan produk.

Reaksi dari turut tegugat akan gugatan yang disampaikan penggugat adalah menolaknya, sebab gugatan telah melewati batas waktu pengajuan gugatan yaitu 5 tahun yang terhitung sejak tanggal disahkannya merek baru, berhubung merek tergugat adalah merek yang merupakan lanjutan (perpanjangan), tepatnya tanggal 24 februri 1997 maka penggugat harusnya mengajukan gugatan pembatalan merek maksimal tanggal 24 Februari 2002 sesuai dengan regulasi yang ada, yakni Pasal 77 ayat 1 undang-undang MIG. Turut tergugat menggangap bahwa tergugat melakukan pendaftaran dengan iktikad baik terbukti dengan lolosnya tergugat dari proses pemverifikasian data formalitas dan substantif, sehingga mendapatkan sertifikat yang diterbitkan oleh DJKI atas persetujuan Menteri.

Menurut penelitian ini permasalahan mengenai iktikad tidak baik memang kerap terjadi, terutama dalam pelaksanaan pendaftaran merek dagang baru di Indonesia, hal ini menjadi salah satu kelemahan dari DJKI, sebab lembaga ini tidak boleh menampik permohonan pendaftaran merek apabila telah sesuai dengan kriteria dalam undang-undang dan memenuhinya, maka memang cukup sulit untuk membuktikan apakah pendaftar memiliki unsur iktikad tidak baik dalam mendaftarkan mereknya. ${ }^{29}$ Mayoritas pembuktian terhadap unsur tidak baik dilaksanakan dalam sidang pengadilan, namun menurut penelitian ini hal tersebut dapat diminimalisir dengan membentuk tim pemeriksaan khusus di DJKI untuk mendeteksi dan mengumpulkan informasi terkait merek baru, hal ini memang cukup memakan waktu, biaya dan tenaga tapi cukup efektif untuk meminimalisir adanya unsur ketidakjujuran (iktikad tidak baik) saat melakukan pendaftaran merek baru. Tergugat pun berpendapat bahwa berdasarkan sistem first to file, tergugat lah yang memiliki iktikad baik sedangkan penggugat beriktikad tidak baik, hal ini ditandai dengan penggugat mendaftarkan mereknya setelah tergugat mendaftarkan terlebih dahulu yaitu pada tanggal 28 April 2014, sedangkan tergugat telah mendaftarkan mereknya sejak 15 april 1987 dan melakukan perpanjangan merek setiap 10 tahun.

${ }^{29}$ Wilson Wijaya and Christine S.T. Kansil, “Analisis Kekuatan Unsur Itikad Baik Pada Pelaksanaan Pendaftaran Merek Di Indonesia (Studi Kasus Putusan Mahkamah Agung Nomor 364K/Pdt.Sus-HKI/2014) Berdasarkan Undang-Undang Nomor 20 Tahun 2016," Jurnal Hukum Adigama 1, no. 1 (July 23, 2018): 125, https://doi.org/10.24912/adigama.v1i1.2181. 
Penggugat selain mendalilkan iktikad tidak baik maka mendalilkan juga mengenai unsur persamaan secara fundamental dengan merek terkenal karena sesuai Pasal 21 undang-undang MIG yang menjadi dasar dari pengugat mendalilkan hal seperti ini karena merasa bahwa mereknya merupakan merek terkenal yang didasari dengan bukti merek milik penggugat yang telah diakui diberbagai negara melalui sertifikat merek, disamping itu tanggapan dari turut tergugat mengenai permasalahan merek terkenal, harus dibuktikan secara nyata baik bukti otentik berupa surat menyurat, pengakuan dari masyaraat luas, adanya branding secara continue dari merek penggugat, tergugat berpendapat bahwa keterkenalan untuk suatu merek tidak bersifat statis, maka dari itu harus dibuktikan secara nyata mengenai branding yang dilakukan oleh penggugat.

Menurut pendapat bapak Hardi Nurcahyo, DJKI belum memiliki sistem untuk menetapkan merek berkategorikan merek terkenal atau tidak, untuk memastikannya dapat dilakukan oleh pemohon pendaftar merek untuk mengeceknya sesuai dengan regulasi yang diakui negara Indonesia (UU MIG, Peremenkumham 67 tahun 2016, Yursipudensi MA tahun 2002 dan peraturan internasioonal) mengenai kualifikasi dari merek terkenal.

Berdasarkan analisis penelitian ini menautkan antara bukti-bukti yang ditampilkan dalam persidangan oleh penggugat dan isi Pasal 18 ayat 3 Permenkumham Nomor 67 tentang Merek. Bahwa indikator merek populer (terkenal) ialah mengenai pengetahuan masayarakat luas, branding besar-besaran yang dilakukan pemilik merek dan wilayah merek terebut didistribusikan selain Indonesia. Jika menelaah dan mengamati bukti yang diajukan oleh penggugat maka sudah sangat cukup jika melihat pembuktian yang ditampilkan oleh penggugat, karena dalam bukti-bukti tersebut berupa:

a. Terdapat permohonan dan sertifikat merek diberbagai negara internasional seperti ; Australia, Benelux, Brunei Darussalam, Kanada, Hongkong, India, Nepal, Papua New Guinea, Republik Singapura, Afrika Selatan, Republik Rakyat Cina, Thailand, Filipina;

b. Telah melakukan branding di Indonesia dan luar negeri sejak tahun 2010 sampai tahun terjadinya sengketa ini, melalui media cetak dan media elektronik;

c. Masyarakat luas telah mengetahui merek penggugat terbukti dengan presiden ke 6 yang penggugat untuk menghadiri acara dan kerja sama berbagai pihak dengan penggugat.

Untuk mendukung kekuatan pembuktian terhadap merek terkenal milik penggugat, dihadirkan saksi ahli oleh penggugat atas nama Parulian Paidi Aritonang, yang mengatakan, ketidakjujuran mencakup antara lain (asumsi untuk meniru, mendistorsi, mengikuti berbagai merek untuk kebutuhan bisnis mereka dan dapat membawa keadaan kontes bisnis modern, sesuai undang-undang nomor 
5 tahun 1999 tentang Persaingan Usaha Tak Sehat), ahli pun berpendapat bahwa regulasi merek terkenal diatur dibeberapa peraturan International dan nasional seperti Paris Convention, TRIPs Agreement, Joint Recommendation Proficient Protection of wellknown Mark (WIPO), didalam cakupan nasional tentang merek terkenal disinggung dalam Pasal 21 ayat 1 dan penjelasannya dalam UU MIG, selain itu terdapat di Pasal 18 Permenkumham nomor 67 tahun 2016. Pelanggaran merek terkenal dapat berupa pencemaran terhadap goodwill (reputasi) dari merek terkenal tersebut.

Dalam sengketa merek dagang ini penggugat telah melakukan pendaftaran merek kepada DJKI untuk kelas 25, namun ternyata dalam bank data DJKI terdapat merek serupa milik tergugat dengan kelas 25, maka penggugat berasumsi bahwa tujuan mendaftarkan merek tersebut dengan unsur ketidakjujuran saat melakukan pendaftaran dan memiliki kemiripan pada dasarnya dengan merek terdaftar yang terkenal milik penggugat yang telah dibuktikan dengan sertifikat hak merek dibeberapa negara selain Indonesia, berdasarkan pertimbangan majelis hakim dalam pengadilan ini maka putusan yang diberikan oleh Hakim Pengadilan Niaga Jakarta Pusat Yaitu :

a. Menyetujui gugatan penggugat seluruhnya;

b. Mengutarakan penggugat merupakan pemohon untuk pendaftaran merek dengan iktikad baik;

c. Mengutarakan merek dagang milik penggugat yaitu 'EIGER' adalah merek terkenal;

d. Mengutarakan tergugat merupakan pemohon beriktikad buruk ketika mendaftarkan merek dagang dengan nomor IDM000495808 untuk kelas 25 dan nomor IDM000087029 untuk kelas 25 juga;

e. Mengutarakan untuk DJKI untuk membatalkan merek tergugat dari pangkalan data DJKI dan sebarkan dalam berita merek yang sebenarnya sesuai dengan pedoman merek yang bersangkutan;

f. Mengutarakan kepada DJKI bahwa mengabulkan seluruh permohonan merek 'EIGER' atas unsur merek terkenal;

g. Menghukum tergugat membayar biaya ganti rugi perkara.

Di dalam sengketa ini tanggungjawab DJKI yang merupakan pemeriksa untuk merek dalam melaksakanan tugas pokoknya masih terdapat beberapa kelalaian dan tidak sesuai dengan harapan, hal ini disebabkan terdapatnya gugatan dari pihak berkepentingan mengenai mereknya terutama merek yang merupakan merek terkenal, iktikad baik dan juga persamaan secara fundamental, menjadi dasar permasalahan, hal ini terjadi karena cukup sulitnya pembuktian untuk permasalahan tersebut dilain sisi kurangnya fasilitas yang disediakan negara untuk melakukan penelusuran terhadap merek yang sudah diakui sebagai merek terkenal. 
Penelitian ini berpendapat alasan masih terdapatnya pemboncengan terhadap merek terkenal walaupun sudah terdapat lembaga DJKI adalah karena adanya kekosongan hukum dan bagian khusus, karena saat ini DJKI menerima semua pendaftaran merek baru dan itu merupakan hak dari pendaftar karena dilindugi oleh undang-undang, sehingga apabila terdapat merek baru yang melakukan tindakan pemboncengan kepada merek terkenal maka akan tetap diterima apabila sudah sesuai prosedur, hal ini memang kontradiktif dengan pernyataan diundang-undang MIG bahwa semua yang memiliki komponen kesamaan utama dengan merek terkenal harus ditolak hal ini juga dikarenakan tidak ada penjabaran secara khusus mengenai persamaan secara fundamental wujudnya seperti apa, kemudian muncul permasalahan baru sebab belum maksimalnya bank data DJKI, hal ini terbukti dengan banyaknya sengketa mengenai merek terkenal rata-rata pemasalahannya sama yaitu mengenai merek terkenal sebab saat ini merek terkenal baru sah apabila diputuskan oleh pengadilan niaga. Oleh sebab itu perlu adanya regulasi khusus mengenai merek terkenal agar terciptanya kejelasan dan dibuatnya lembaga survey khusus untuk menentukan merek terkenal sesuai dengan syarat-syarat yang baik sehingga tidak perlu menunggu putusan dari pengadilan.

Maka tanggungjawab dari DJKI sebagai pihak yang memiliki tugas dan taggungjawab terhadap pendaftaran dan pemverifikasian data dari merek-merek yang ada, tidak hanya sebatas menjalankan putusan saja akan tetapi harus adannya ketelitian dalam pengecekan merek yang baru mendaftar supaya tidak terdapat pihak yang dirugikan, perlu adanya sosialisasi kepada pelaku bisnis yang belum mendaftarkan mereknya, disisi lain harus adanya prinsip kehati-hatian sebab jika tidak, dapat terkena sanksi pidana sebagaimana diatur didalam Pasal 413 sampai 417 KUHP tentang kejahatan jabatan dan pasal 552 sampai 559 tentang pelanggaran jabatan. Berdasarkan pendapat bapak Hardi Nurcahyo selaku orang yang berada dilingkungan DJKI, bahwa pada dasarnya DJKI memiliki usaha untuk meminimalisir pembatalan merek yang terdapat di Indonesia, hal ini ditujukan dengan pemeriksa merek berusaha sebaik mungkin dengan berpedoman kepada undang-undang dan peraturan mengenai merek terutama tentang unsur persamaan secara fundamental, bahwa pada prinsipnya DJKI menolak merekmerek yang memiliki kemiripan pada pokoknya terutama terhadap merek terkenal, selain itu DJKI juga melakukan sosialisasi dan memiliki anggaran khusus dan bekerja sama dengan Divisi Penyuluhan Hukum pada DJKI yang menargetkan kepada UKM (usaha kecil menengah), karena mereka beranggapan bahwa UKM lebih sulit mendapatkan informasi seputar merek jika dibandingkan dengan perusahaan besar. 


\section{E. PENUTUP}

Penerapan perlindungan hukum bagi merek terkenal di Indonesia adalah hal yang penting guna menjamin kepastian hukum dari pemegang hak merek terkenal yang sudah diakui negara, saat ini belum ada peraturan khususnya, sedikit jaminan perlindungan hukum bagi merek terkenal saat ini terdapat didalam Pasal 21 undang-undang nomor 20 tahun 2016 tentang MIG beserta dengan penjelasannya, kemudian didalam Pasal 84 Permenkumham nomor 67 tahun 2016 tentang Pendaftaran Merek dan terakhir didalam Statuta MA nomor 022/HKI/2012, perlindungan hukum dapat terlaksana apabila adanya kesadaran dari masyarakat mengenai merek terkenal serta terciptanya budaya hukum masayarakat Indonesia yang Obey (taat hukum). Tanggungjawab merupakan hal yang selinier dengan kewenangan, dalam ranah institusi negara pertanggungjawaban terdapat 2 kategori yaitu pertanggungjawaban atas nama instansi dan atas nama pribadi, DJKI memiliki tanggungjawab atas pembatalan merek yang dalam pengadilan dan sampai sekarang tidak ada pedoman yang jelas mengatur kewajiban tanggungjawab DJKI, akan tetapi bentuknya dapat berupa melakukan putusan pengadilan dan melakukan penyuluhan hukum untuk mencegah tindakan serupa terjadi, disisi lain bentuk pertanggungjawaban dapat berupa hukuman sesuai dengan KUHP tentang kejahatan jabatan atau pelanggaran jabatan, saran dari penulisan ini adalah dengan dibuatnya peraturan tersendiri mengenai merek terkenal dan tanggungjawab dari DJKI terhadap suatu merek yang telah dibatalkan oleh pengadilan karena memiliki komponen kemiripan pada tingkat fundamental.

\section{DAFTAR PUSTAKA}

Ahmad, Mukti Fajar \& Yulianto. Dualisme Penelitian Hukum Normatif \& Empiris. Yogyakarta: Pustaka Pelajar, 2017.

Ansori, Lutfil. "Diskresi Dan Pertanggungjawaban Pemerintah Dalam Penyelenggaraan Pemerintahan." Jurnal Yuridis 2, no. 1 (2015): 134-50. https://doi.org/https://doi.org/10.35586/jyur.v2i1.165.

Anugrah, Sendy. "Unsur Persamaan Pada Pokoknya Dalam Pendaftaran Merek Menurut Undang-Undang Nomor 20 Tahun 2016 Tentang Merek Dan Indikasi Geografis Dan Penerapannya Dalam Praktik Dihubungkan Dengan Pelanggaran Terhadap Merek Terkenal.” Aktualita (Jurnal Hukum) 2, no. 1 (July 19, 2019): 18-37. https://doi.org/10.29313/aktualita.v2i1.4663.

Arifin, Zaenal, and Muhammad Iqbal. "Perlindungan Hukum Terhadap Merek Yang Terdaftar." Jurnal Ius Constituendum 5, no. 1 (2020): 56-60. https://doi.org/https://doi.org/10.26623/jic.v5i1.21172.

Ashidqie, Jimly. Menuju Negara Hukum Yang Demokratis. Jakarta: Sekretariat Jenderal dan Kepaniteraan Mahkamah Konstitusi, 2008.

Ayuna Putri, Sherly, Tasya Safiranita Ramli, and Hazar Kusmayanti. 
"Penyelesaian Sengketa Merek Terkenal Sephora Atas Dasar Persamaan Pada Pokoknya Berdasarkan HIR Dan Undang-Undang Nomor 15 Tahun 2001 Tentang Merek." Jurnal Hukum Positum 4, no. 2 (December 21, 2019): 57-67. https://doi.org/10.35706/positum.v4i2.3182.

Bafadhal, Thoyyibah. "Perlindungan Hukum Terhadap Merek Terkenal Di Indonesia." Undang: Jurnal Hukum 1, no. 1 (June 1, 2018): 21-41. https://doi.org/10.22437/ujh.1.1.21-41.

Budiman, Citra Rosa. "Perlindungan Hukum Terhadap Merek Terkenal (WellKnown) Di Indonesia." Reformasi Hukum 23, no. 1 (November 27, 2019): 1-18. https://doi.org/10.46257/jrh.v23i1.54.

Bustani, Sukmo Hanggarjito \& Simona. "Tanggung Jawab Ditjen KI Terhadap Pembatalan Merek Dagang COFFEEBERRY (Studi Putusan Mahkamah Agung Nomor 769K/PDT.SUS.HKI/2019)" 3, no. 1 (2020): 822-40. https://doi.org/https://doi.org/10.24912/adigama.v3i1.8928.

Cahyani, Fenny, Muhammad Junaidi, Zaenal Arifin, and Kadi Sukarna. "Kedudukan Hak Imunitas Advokat Di Indonesia." USM Law Review 4, no. 1 (2021): 146-60. https://doi.org/https://doi.org/10.26623/julr.v4i1.3328.

Desmayanti, Rakhmita. "Tinjauan Umum Perlindungan Merek Terkenal Sebagai Daya Pembeda Menurut Prespektif Hukum Di Indonesia." Jurnal Cahaya Keadilan 6, no. 1 (April 30, 2018): 1-21. https://doi.org/10.33884/jck.v6i1.874.

Erwin, Muhammad. Filsafat Hukum. Jakarta: Raja Grafindo, 2012.

Fajar, Mukti, Yati Nurhayati, and Ifrani Ifrani. "Iktikad Tidak Baik Dalam Pendaftaran Dan Model Penegakan Hukum Merek Di Indonesia." Jurnal Hukum Ius Quia Iustum 25, no. 2 (May 2018): 210-36. https://doi.org/10.20885/iustum.vol25.iss2.art1.

Falarungi, Wahyudy, Hambali Thalib, and Syamsuddin Pasamai. "Penegakan Hukum Terhadap Penjualan Pakaian Merek Palsu Di Pasar Senteral Kota Makassar." Journal of Lex Philosophy (JLP) 1, no. 2 (December 19, 2020): 151-62. https://doi.org/10.52103/jlp.v1i2.214.

Iqbal, Mohammad, and Erdyanto Dwi Nugroho. "Legal Protection Of Famous Trademarks." USM Law Review 4, no. 1 (2021): 105-16. https://doi.org/https://doi.org/10.26623/julr.v4i1.3460.

Jacklin Mangowal. "Perlindungan Hukum Merek Terkenal Dalam Perspektif Undang-Undang Nomor 20 Tahun 2016 Tentang Merek.” Lex Et Societatis 5, no. 9 (2017): 22-29.

Karina, Rahmadia Maudy Putri, and Rinitami Njatrijani. "Perlindungan Hukum Bagi Pemegang Hak Merek Dagang IKEA Atas Penghapusan Merek Dagang.” Jurnal Pembangunan Hukum Indonesia 1, no. 2 (May 29, 2019): 194-212. https://doi.org/10.14710/jphi.v1i2.194-212.

Kementrian hukum dan HAM. Peraturan Menteri Hukum dan HAM Tentang Pendaftaran Merek, Pub. L. No. 67 (2016). https://peraturan.bpk.go.id/Home/Details/133289/permenkumham-no-67tahun-2016.

Legalakses.com. "“Persamaan Pada Pokoknya' Dalam Hak Merek." Legalakses.com, n.d. https://www.legalakses.com/persamaan-pada- 
pokoknya/.

Mahanani, Anajeng Esri Edhi. "Rekonstruksi Budaya Hukum Berdimensi Pancasila." Jurnal Yustika Media Hukum Dan Keadilan 22, no. 2 (2019): 110. https://doi.org/https://doi.org/10.24123/yustika.v22i01.

Mahkamah Agung. Yurispudensi Mahamah Agung, Pub. L. No. 22K/HaKI/ (2002).

Pemerintah pusat. Undang-Undang (UU) Tentang Ombudsman Republik $\begin{array}{llllll}\text { Indonesia, } & \text { Pub. } & \text { L. } & \text { No. } & 37 & \text { (2008). }\end{array}$ https://peraturan.bpk.go.id/Home/Details/39708.

Pemerintah Pusat. Undang-Undang (UU) Tentang Merek dan Indikasi Geografis, Pub. L. No. 20 (2016). https://peraturan.bpk.go.id/Home/Details/37595/uuno-20-tahun-2016.

Pindayani, Hertanti. "Tanggung Jawab Direktorat Jenderal Hak Kekayaan Intelektual Terhadap Pemegang Hak Atas Merek Dalam Hal Ada Putusan Pembatalan Merek." Authentica 1, no. 1 (December 8, 2018): 42-50. https://doi.org/10.20884/1.atc.2018.1.1.8.

Riduan, Syahrani. Rangkuman Intisari Ilmu Hukum. Bandung: Citra Aditya Bakti, 1999.

S, Laurensius Arliman. Menuju Negara Hukum Yang Demokratis. Yogyakarta: Deepublish, 2015.

Safiranita, Tasya, Sherly Ayuna Putri, and Hazar Kusmayanti. "Penyelesaian Sengketa Merek Terkenal 'SEPHORA' Atas Dasar Persamaan Pada Pokoknya Berdasarkan Herzien Inlandsch Reglement (HIR) Dan UndangUndang Merek." Dialogia Iuridica: Jurnal Hukum Bisnis Dan Investasi 9, no. 1 (November 30, 2017): 112-21. https://doi.org/10.28932/di.v9i1.734.

Soekanto, Sarjono. Faktor-Faktor Yang Mempengaruhi Penegakan Hukum. Jakarta: Rajawali Pers, 2012.

Wijaya, Wilson, and Christine S.T. Kansil. "Analisis Kekuatan Unsur Itikad Baik Pada Pelaksanaan Pendaftaran Merek Di Indonesia (Studi Kasus Putusan Mahkamah Agung Nomor 364K/Pdt.Sus-HKI/2014) Berdasarkan UndangUndang Nomor 20 Tahun 2016." Jurnal Hukum Adigama 1, no. 1 (July 23, 2018): 1-25. https://doi.org/10.24912/adigama.v1i1.2181. 